\title{
Language Anxiety and Attitude of Secondary School Students towards Learning English
}

\author{
Muhammad Athar Hussain*
}

\begin{abstract}
In countries where English is taught as a foreign language, learners suffer various levels of being anxious and develop a specific attitude towards English. The paper examined foreign language anxiety of $10^{\text {th }}$ grade students and their attitude towards foreign language learning. Sample of the study was 360 male and 360 female students of 10th grade students of public sector secondary schools from six districts of the Punjab Province of Pakistan. Foreign Language Classroom Anxiety (FLCAS) scale was used to investigate anxiety of the students and attitude towards English was found by using English language attitude scale. The data were analyzed quantitatively using SPSS. $t$-test was used to find out gender differences for language anxiety and attitude. Relationship of anxiety with attitude of the students was determined though Pearson product moment coefficient. Results revealed that significant differences existed between male and female students for foreign language anxiety and attitude towards foreign language learning. Results also indicated that significant negative correlation was found between foreign language anxiety and students' attitude towards foreign language learning. Girls showed less anxiety in English language class and had more positive attitude towards English. It was suggested that training might be given to English language teachers on modern pedagogical patterns. English language Curriculum might be redesigned keeping the context of the learners in mind.
\end{abstract}

Keywords: language learning, foreign language anxiety, attitude towards English, gender differences.

\footnotetext{
* Assistant Professor, ECE \& ETED, Allama Iqbal Open University, Islamabad. Email: Muhammad.athar@aiou.edu.pk
} 


\section{Introduction}

Learning English as a foreign language has become a vital part of students' academic skills and most of the time success of their career is closely connected with success in English language. Quite a large number of students take learning of English as a challenge and sometimes it becomes a problem for them. Various internal and external factors are associated with language learning which help in lowering or increasing language acquisition process. External factors include quality of language instruction, teacher with diverse background and curriculum while internal factors consist of attitude, self-image, self-confidence; anxiety etc. internal factors significantly exert influence on performance and success of students in a foreign language course (Buyukkarci, 2016). As positive attitudes are helpful in learning a foreign language, so it is worthwhile to pay attention to investigate internal factors such as anxiety and attitude towards learning English as a foreign language.

One of the strongest intrinsic motivational variables in the classroom is anxiety. Language anxiety is referred to as the feeling of being tense, worried, nervous and feeling fear when students start learning a foreign language.

Horwitz, Horwitz and Cope (1986) stated that anxiety can be taken as subjective feeling of tension, apprehension, nervousness and worry which come up with the automatic nervous system. Considering English as a foreign language to learning in Pakistan, it influences the language learning process as internal factor. Another internal factor which affects when learning a foreign language is attitude. A learner's attitude towards learning a foreign language determines how the learner would proceed in foreign language learning. Anxiety caused by fear of the teacher or even by being unusual circumstances such as in a strange room for an examination may tend to act as an inhibitor of students' activity.

Zimbardo and Leippe (1991) referred attitudes as predispositions to respond. Attitudes explain how a situation is perceived. Attitudes vary in direction (either positive or negative), in degree (the amount of being positive or being negative), and in intensity (the amount of commitment with which a position is held; Smith, 2003). Attitudes determine and help to decide the way you adopt for learning. Developing positive attitude towards learning of English as a foreign language requires one to be indulged in a foreign culture, that is, English language environment and then to learn a foreign language is a hard task for non-English learners. Many researchers have also focused on finding relationship between achievement in English language learning and attitude toward it (İnal, 
Evin \& Saracaoglu, 2004). Studies also showed that students with high achievement had positive attitudes towards English language learning and students with positive attitudes are less anxious (Al samadeni and Ibnian, 2015; Liu and Chen, 2013). Both attitude and anxiety in language learning may have negative or positive connection with foreign language learning. It is important to examine relationship between anxiety and attitude of students towards learning of English as a foreign language in Pakistan.

\section{Literature Review}

English language cannot be overlooked in today's global world where students have to connect with the whole world. It is an international communication language. Further, English today is the requirement of almost in each and every field of life. It is best known as foreign language in Pakistan and being studied as a foreign language. English is also the source and medium of providing information and instructions at all levels of education in Pakistan. Oxford and Shearin (1999) defined foreign language as "A language which is learned in a place where it is not usually utilized as the medium of everyday communication is known as foreign language.

In Pakistan English as a Second or foreign language has fast expanded during the last few decades. Public and private sector offered a number of language courses in English skills, that is, reading, writing, speaking and listening, from primary to tertiary level of education in order to enable students to communicate in English during their studies and in professional life. Students face difficulties in understanding and utilizing English in their study or in daily life. In this way several research studies have been examined the relationship of language anxiety with academic skills and professional progress. Language anxiety as a definite feature of language acquisition has been studied frequently in the past few decades; it has for some time been perceived as a deterrent in second or foreign language learning. Language anxiety plays an important part and being considered as a keyaspect in foreign language learning (Gardner \& MacIntyre, 1992).

\section{Language Anxiety}

In last few decades language anxiety has been frequently explored in different contexts by different researchers. Research findings from earlier conducted research studies on this phenomenon have uncovered anxiety 
as an obstacle in foreign language learning. According to Young (1999) foreign language anxiety is the "worry and negative emotional reaction when learning or utilizing a second language". Anxiety in using English language manipulates students' achievement and makes it harder to achieve their goals. Anxiety in language learning can play a disturbing and influential part in students' target achievement (Khattak, Jamshed, Ahmad, Mirza \& Baig, 2011). Meager performance by Students in language learning and in academia is caused by high level of language anxiety (Comunian, 1993; Mwamwenda, 1994; Kamarulzaman, Ibrahim, Yunus, \& Ishak, 2013).

\section{Gender Differences in Foreign Language Anxiety}

Research studies on language learning found language anxiety differences between male and female students when they were learning English as a foreign language. Research studies which examined students' attitude and anxiety in learning a foreign language provided contrasting results when they studied these variables with the demographic variable of gender. A study conducted by Abidin, Mohammadi, \& Alzwari (2012) found significant attitudinal differences while exploring male and female students' attitude towards learning a foreign language. Another study exploring variable of gender, conducted by Fakeye (2010) found that students' attitude towards foreign language learning is not statistically significant different according to the gender. Male and female students display almost same attitude towards foreign language learning. Study conducted by Aida (1994) exploring Japanese students' foreign language classroom anxiety found that male and female students did not have significant different level of foreign language learning anxiety. On the other hand there are studies which present the contrary results with the above mentioned studies and explored higher foreign language leaning anxiety among female students as compared to male students (Bensoussan \& Zeidner, 1989; Abu-Rabia, 2004). While there are studies which explored that females show low anxiety than male students in foreign language learning. A study conducted by Shi \& Liu (2006) had different results and discovered that female students experience a lower level of anxiety than males in learning a foreign language.

The above discussed results of various studies showed mixed results about students' anxiety and attitude towards foreign language (English) learning. Research studies revealed different results in different contexts. Keeping this in mind the present research study investigated the anxiety 
and attitude of Pakistani students towards English language learning as a foreign language.

\section{Methodology}

The study was quantitative in nature which employed survey method to investigate gender differences in language anxiety and attitude towards leaning a foreign language. It also examined relationship between language anxiety and attitude.

\section{Sample}

Sample of the study was 720 10th grade students out of which 360 were girls and 360 were boys. The sample was selected using stratified random sampling technique from six districts of the Punjab Province. Their age ranged from 15 to 17 years. The sampled students were studying in public sector high schools of the Punjab Province and experienced same curriculum and examination system. English was taught as compulsory subject from grade one to graduate level in Pakistan and since 2010 the Government of the Punjab had introduced all subjects in English for Primary schools.

\section{Instruments}

Foreign language classroom anxiety scale and Attitude scale towards English were used as research instruments to collect data. Reliability coefficient was calculated using Cronbach alpha that ranged from .77 to .82 for foreign language anxiety scale and ranged from .81 to .87 for language attitude scale. Validity of the instruments was established through experts' opinion. In the light of the suggestions of the experts, some items of attitude scale were modified and some were deleted. The respondents completed the questionnaire using five point scale ( $1=$ Strongly agree to $2=$ Strongly disagree). The foreign language classroom anxiety scale had three subscales, namely, Communication apprehension, Test anxiety and Fear of negative evaluation. The attitude scale towards the learning of English had two subscales, that is, Enjoyment of English lessons, and Adoption of English language attitude. 


\section{Results}

Data collected from the two instruments were analyzed and interpreted here.

Table 1

Gender Differences in Foreign Language Classroom Anxiety

\begin{tabular}{|c|c|c|c|c|c|c|}
\hline \multicolumn{3}{|l|}{ Subscales } & $\mathrm{N}$ & Mean & $S D$ & t-value \\
\hline \multicolumn{3}{|l|}{ Communication } & & & & \\
\hline \multirow{3}{*}{\multicolumn{2}{|c|}{ Apprehension }} & & 360 & 36.41 & 8.155 & 2.558 \\
\hline & & Female & & & & \\
\hline & & & 360 & 34.86 & 8.100 & \\
\hline \multirow[t]{4}{*}{ Test Anxiety } & & Male & & & & \\
\hline & & & 360 & 31.97 & 9.431 & 2.731 \\
\hline & & Female & & & & \\
\hline & & & 360 & 30.06 & 9.369 & \\
\hline \multirow{3}{*}{ Evaluation } & Negative & Male & & & & \\
\hline & & Female & 360 & 35.01 & 8.949 & 2.721 \\
\hline & & & 360 & 33.23 & 8.632 & \\
\hline \multirow{4}{*}{\multicolumn{2}{|c|}{ FLCAS Overall }} & Male & & & & \\
\hline & & & 360 & 103.41 & 24.814 & 2.879 \\
\hline & & Female & & & & \\
\hline & & & 360 & 98.17 & 24.092 & \\
\hline
\end{tabular}

$d f=718 ; p<.05$

Table 1 reflects that girls are less anxious on dimension of communication apprehension of foreign language classroom anxiety scale. $t$-test value shows significant difference of girls and boys mean score i.e. girls, 34.86 and boys, 36.41 that indicates that boys have higher level of communication apprehension in foreign language class than the girls. Girls with mean 30.06 and boys with mean 31.97 on test anxiety lead to the finding that boys have higher level of test anxiety than the girls in English class. The difference is significant at .01 level. Significant difference at .01 level was found between girls and boys mean scores on the dimension of Fear of negative evaluation. The boys with mean 35.01 show that they are more afraid of negative evaluation and get anxious than the girls with mean 33.23. 
Table 2

Gender Difference in Attitude towards Foreign Language Learning

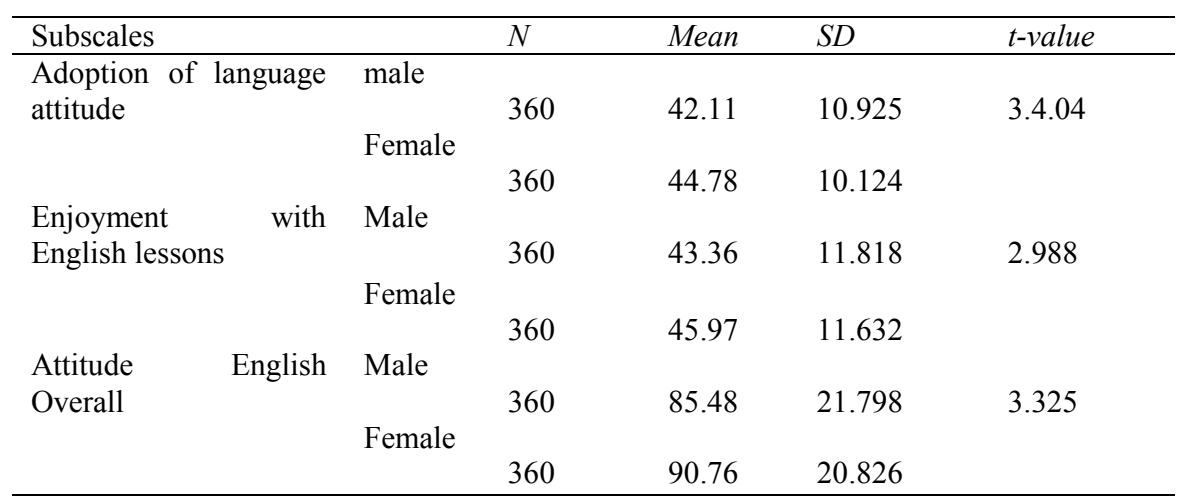

$d f=718 ; p<.05$

Results from table 2 suggest that girls are more positive in adopting language leaning attitudes. On adoption of English language learning attitudes, girls mean score 44.78 is higher than boys mean score 42.11 . Boys are slower in adopting English language learning attitudes. $t$-test value shows significant difference at .01 level. Girls have higher mean score 45.97 towards enjoyment of English lessons than boys, mean= 43.36. $t$-value shows that the significant difference. Girls are more positive towards enjoyment of English lessons than boys.

Table 3

Correlation between Foreign Language Classroom Anxiety and Attitude towards Learning of English

\begin{tabular}{|c|c|c|c|}
\hline FLCAS Dimensions & $\begin{array}{l}\text { Attitude } \\
\text { Overall }\end{array}$ & $\begin{array}{l}\text { Adoption of } \\
\text { language attitude }\end{array}$ & $\begin{array}{l}\text { Enjoyment } \\
\text { of English } \\
\text { Lesson }\end{array}$ \\
\hline & $\mathrm{r}$ & $\mathrm{r}$ & $\mathrm{r}$ \\
\hline FLCAS & $-.957 * * *$ & $-.907 * * *$ & $-.926 * * *$ \\
\hline $\begin{array}{l}\text { Communication } \\
\text { Apprehension }\end{array}$ & $-.885 * * *$ & $-.847 * * *$ & $-.849 * * *$ \\
\hline Test Anxiety & $-.875 * * *$ & $-.820 * * *$ & $-.855 * * *$ \\
\hline $\begin{array}{l}\text { Fear of Negative } \\
\text { Evaluation }\end{array}$ & $-.910 * * *$ & $-.864 * * *$ & $-.879 * * *$ \\
\hline
\end{tabular}

Table 3 reveals that scores of FLCAS and that of Attitude scale correlated significantly. There is found high negative correlation between 
FLCAS with overall Attitude scale, $r=-.957$ at .001 level and with the subscale Adoption of English language attitude $(\mathrm{r}=-.907$ at .001$)$; Enjoyment of English lessons $(r=-.926$ at .001$)$. This suggests that anxiety in foreign language class has strong relationship with positive/negative attitude in a foreign language classroom. Negative correlation shows that the students have lower level of adoption and enjoyment that has a significant relationship anxiety in the foreign language classroom. Further is that, each subscales of FLCAS is negatively correlated with the subscales of Attitude scale. The subscale Communication apprehension of FLCAS reveals that the students who are anxious in communication would have lower adoption and enjoyment towards the learning of English as the data shows about Communication apprehension, $\mathrm{r}=-.885$ at .001 with the overall Attitude scale; with subscale Adoption of language attitude, $r=-.847$ at .001 ; with Enjoyment of English lessons, $r=-.847$ at .001 which clearly reveals that in a classroom where students face communication apprehension, they might have negative attitude towards the learning of English.

Test anxiety subscale reveals negative correlation with Adoption of English language attitude, $r=-.820$; with Enjoyment of English lessons, $r$ $=-.855$ and both are significant at .001 . This suggests that the students having anxiety in their performance, there would be negative attitude towards language learning. Then the Fear of negative evaluation shows negative correlation $r=-.910$ with total Attitude scale; $r=-.864$ with Adoption of language attitude and $r=-.879$ with Enjoyment of English lessons, significant at .001 . This negative correlation reveals that the students would have lower level of adoption and enjoyment when they undergo anxious feelings in foreign language classroom.

\section{Discussion and Conclusion}

There exists a negative correlation between foreign language anxiety and 10th grade students' attitude towards English language learning. Attitude and language learning have close link and influence upon each other. Data show that student feel communication apprehension as they do not feel confident in English language class. They also experience test anxiety in English language class because most of the time they feel they would not be able to perform better in English test. These findings were supported by Naiman et al. (1978) who suggested that the link of attitudinal variables with foreign language learning was simply that they make the students enthusiastic about learning the second language. Stark and Paltridge (1996) also reported that there existed a strong link 
between attitude and language learning process. Dunn and Harris (1998) have associated the inside classroom environment with the feelings, experiences and perceptions of the students. Twenge (2000) stated that language anxiety grows with when there is a possibility of classroom environmental threat. Positive attitude would lead students start enjoying foreign language learning.

Negative relationship between dimensions of foreign language classroom anxiety and dimensions of language attitude show that low language attitude might support high level of language anxiety. For language teaching and learning in high schools, content material might be revised and emphasis might be given on worksheets, notes by the language teacher and sample guidebooks.

\section{Recommendations}

Interactive teaching method may be used in English language class so that students might be able to take part in class discussions that might minimize their English language anxiety. Fear of negative evaluation might be removed by giving encouraging comments on their work and making them confident in the classroom. Poor performance of the students should not be punished but they should be motivated to investigate and involve in classroom activities. Students' enjoyment in English lessons might be increased by making lessons easier and interesting. In this way, their anxiety in English class might be reduced. English language teachers might be trained to motivate students to develop positive attitude towards English language learning by familiarizing the students with the utilization of library facilities and practice of short sentences in daily routine activities. Exposure to educational English movies, academic English talks and even some games may help removing their language anxiety. 


\section{References}

Al samadeni, H. A. \& Ibnian, S. S. (2015). The relationship between Saudi EFL students' attitudes towards learning English and their academic achievement. International Journal of Education and Social Science, 2 (1), 92-102.

Abidin, M. J. Z., Pour-Mohammadi, M., \& Alzwari, H. (2012). EFL students' attitudes towards learning English language: The case of Libyan secondary school students. Asian Social Science, 8,119-134.

Abu-Rabia, S. (2004). Teachers' role, learners' gender differences, and FL anxiety among seventh-grade students studying English as a FL. Educational Psychology, 24(5), 711-721.

Aida, Y. (1994). Examination of Horwitz, Horwitz, and Cope's construct of foreign language anxiety: The case of students of Japanese. The Modern Language Journal, 78(2), 155-168.

Bensoussan, M., \& Zeidner, M. (1989). Anxiety and achievement in a multicultural situation. Assessment in Higher Education, 14(1), 4054.

Büyükkarc1, K. (2016). Is it language learning anxiety and or attitude of university students that determines their academic success? Turkish Online Journal of English Language Teaching (TOJELT), 1(2), 5765.

Comunian, A. L. (1993). Anxiety, cognitive interference, and school performance of Italian children. Psychological reports, 73(3), 747754.

Dunn, R. J., \& Harris, L.G. (1998). Organizational dimensions of climate and the impact on school achievement. Journal of Instructional Psychology, 25,100-115.

Elyildirim, S. \& Ashton, S. (2006). Creating positive attitudes towards English as a foreign language. English Teaching Forum, 4, 2-21.

Fakeye, D. (2010). Students' personal variables as correlates of academic achievement in English as a second language in Nigeria. Journal of Social Sciences, 22, 205-211. 
Gardner, R. C., \& MacIntyre, P. D. (1992). A student's contributions to second language learning. Part I: Cognitive variables. Language Teaching, 25, 211-22.

Horwitz, E. K., Horwitz, M. B., \& Cope, J. (1986). Foreign language classroom anxiety. Modern Language Journal, 70 (2): 125-132. doi: 10.1111/j.1540-781.1986.tb05256.x

İnal S., E., İlke \& Saracaloğlu, A. S. (2004). The relationship between students' attitudes toward foreign language and foreign language achievement. (Paper Presentation) First International Conference DokuzEylül University Buca Faculty of Education, İzmir.

Kamarulzaman, M. H., Ibrahim, N., Yunus, M. M., \& Ishak, N. M. (2013). Language anxiety among gifted learners in Malaysia. English Language Teaching, 6(3), 20-29.

Khattak, Z. I., Jamshed, T., Ahmad, A., \& Baig, M. N. (2011). An investigation into the causes of English language learning anxiety in students at AWKUM. Procedia-Social and Behavioral Sciences, 15, 1600-1604.

Liu, H. \& Chen, T. (2013). Foreign language anxiety in young learners: how it relates to multiple intelligences, learner attitudes, and perceived competence. Journal of Language Teaching and Research, 4 (5), 932-938.

Mwamwenda, T. S. (1994). Test anxiety and academic achievement among South African university students. Psychological reports, 75(3f), 1593-1594.

Naiman, N., Frohlich, M., Stern, H. H., \& Todesco, A. (1978). The good language learner: Research in Education, 7, 285-288.

Oxford, R., \& Shearin, J. (1994). Language learning motivation: Expanding the theoretical framework. Modem Language Journal, 78, 12-28.

Rukh, S. (2014). Students' attitude towards English language learning and academic achievement: a case of business students in Punjab. European Academic Research, 2 (4), 5596-5612.

Shi, Y. Z., \& Liu, Z. Q. (2006). Foreign language reading anxiety and its relationship to English achievement and gender. Journal of Pla University of Foreign Languages, 29(1), 59-65. 
Smith, S. (2003). Teaching challenges and dilemmas. Singapore: Robyn Ewing Rosie Le Cornu Thomson.

Starks, D., \& Paltridge, B. (1996). A note on using sociolinguistic methods to study non-native attitudes towards English. World Englishes, 15(2), 217-224.

Twenge, J.M. (2000). The age of anxiety? Birth cohort change in anxiety and neuroticism. Journal of Personality and Social Psychology, 7(6), 1007-1021.

Young, D. J. (1999). Affect in foreign language and second language learning: A practical guide to creating a low-anxiety classroom atmosphere. Boston, MA: McGraw-Hill.

Zefran, M. (2015). Students' attitudes towards their EFL lessons and teachers: their retrospective study. The Journal of Elementary Education, 8 (1-2), 167-181.

Zimbardo, P. \&Leippe, M. (1991). The psychology of attitude change and social influence. Philadelphia, PA: Temple University Press.

\section{Citation of this Article:}

Hussain, M.A. (2018). Language anxiety and attitude of secondary school students towards learning English. Pakistan Journal of Education, 35(1), 71-82.

Received on: June 06,2017

Revised on: December 28, 2017

Accepted on: February 08, 2018 